\title{
TAJEMNICA KOŚCIOŁA WEDŁUG AMBROZJASTRA *
}

\author{
WSTEP
}

Niniejsze studium zmierza do ujęcia tajemnicy Kościoła w spojrzeniu anonimowego pisarza chrześcijańskiego z IV wieku, którego Erazm z Rotterdamu nazwał Ambrozjastrem ${ }^{1}$. O wyborze tematu zadecydowała nie tylko duża aktualność, jaką obecnie cieszą się rozważania eklezjologiczne, ale przede wszystkim to, że autor należąc do najlepszych komentatorów listów Pawła ${ }^{2}$, a więc tych tekstów natchnionych, w których zawarte są zręby chrześcijańskiej eklezjologii, w dotychczasowych opracowaniach historii dogmatów jest prawie zupełnie niedostrzeżony.

Nie dostrzegały Ambrozjastra stare podręczniki historii dogmatów. J. Tixeront, przedstawiając naukę o Kościele u Ojców Łacińskich IV wieku, wymienia Ambrozjastra obok Hieronima, Ambrożego, Hilarego i Wiktoryna, nie poświęcając mu jednak ani jednego zdania ${ }^{3}$. F. Cayré podaje tylko ogólne dane o autorze i dziełach zupełnie nie dotykając jego teologii ${ }^{4}$. Podobnie sprawa przedstawia się $w$ najnowszych podręcznikach. Wielotomowa Historia dogmatów, wydana przez Herdera, po-

* Artykuł niniejszy stanowi przeredagowany fragment pracy doktorskiej Autora napisanej w Krakowskim Ośrodku Teologicznym.

1 Encyklopedyczne dane o autorze podaje A. Stuiber. Zob. Ambrosiaster. Nachträge zum Reallexikon für Antike und Christentum, w: Jahrbuch für Antike und Christentum, 13 (1970) 119-123. Do naszych czasów zachowały się w całości dwa dzieła Ambrozjastra: Komentarz do Listów Pawła i 127 Kwestii Starego i Nowego Testamentu, one też stanowią bazę źródłową dla niniejszego studium. Wydania krytyczne: Ambrosiastri qui dicitur commentarius in epistulas Paulinas. CSEL. vol. LXXXI, rec. H. J. Vogels, pars prima Vindobonae 1966; pars secunda - 1968; pars tertia - 1969. (Cytujemy: Comm. Rom 1, 1 (1), 9). Pseudo-Augustini Quaestiones Veteris et Novi Testamenti CXXVII. CSEL. vol. L. rec. A. Souter, Vindobonae 1908. (Cytujemy: Q. 1, 1, 13).

2 Komentarz Ambrozjastra jest ,un des plus importantes, le plus important peut-être de ceux qu'ont laissés les écrivains chrétiens de langue latine" pisze G. Bardy. Por. L' Ambrosiaster, w: Dict. Bibl. Suppl., Paris 1928, 225.

3 J. Tixeront, Historie des dogmes dans l'Antiquité Chrétienne, Paris 1921, t. II, 304 .

4 F. Cayré, Précis de Patrologie et d'Histoire de la Théologie, Paris 1931, t. I, 590 . 
święca cały rozdział łacińskiej eklezjologii IV wieku. Mówi obszernie o Hilarym, Ambrożym, Hieronimie i Optacie, a tylko w jednym zdaniu wspomina o Ambrozjastrze 5 . Autorzy jednej z najlepszych Historii Kościoła, przedstawiając na blisko stu stronach rozwój teologii od Soboru Nicejskiego do Chalcedońskiego, nie cytują Ambrozjastra ani razu, chociaż korzystają z pewnych jego wypowiedzi przy omawianiu organizacji kościelnej ${ }^{6}$. Zupełnie analogicznie przedstawia się sytuacja w Nouvelle Histoire de l'Eglise ${ }^{7}$. Eklezjologicznych opinii Ambrozjastra nie uwzględniają nawet tak klasyczne dziela, jak: Le Corps mystique du Christ E. Merscha ${ }^{8}$ i Symbole der Kirche Hugo Rhanera ${ }^{9}$.

Jeżeli chodzi o pisarzy zajmujących się bezpośrednio dziełami Ambrozjastra, to na temat jego eklezjologii zabierają głos C. Martini, W. Mundle i O. Heggelbacher. Pierwszy z nich omawiając teologię Komentarza i Quaestiones jeden z punktów poświęca wprawdzie wyłącznie nạuce - Kościele, ale do tego stopnia upraszcza całe zagadnienie, że właściwie nie mówi nic. Ogranicza się tylko do zasygnalizowania dwu pojęć Kóó́cioła (szerszego i węższego), którymi posługuje się autor; kilka zdań poświęca władzy, jaką według Ambrozjastra posiadał Piotr w Kościele, a dla zreferowania poglądów autora odnośnie organizacji kościelnej przytacza długi fragment komentarza do Ef 4, 11 nie poddając go żadnej analizie ${ }^{10}$. W. Mundle natomiast w wielkim skrócie przedstawia poglądy autora dotyczące organizacji kościelnej, zwłaszcza w czasach apostolskich, nie dotykając aspektu teologicznego ${ }^{11}$. Othmar Heggelbacher interesuje się wyłącznie prawnym aspektem instytucji kościelnych ${ }^{12}$.

W tej sytuacji zapoznanie się ze spojrzeniem Ambrozjastra na tajemnicę Kościoła i umożliwienie w ten sposób konfrontacji jego podejścia z naszym, wydaje się rzeczą godną uwagi.

5 P. T. Camelot, Die Lehre von der Kirche. Väterzeit bis ausschliesslich Augustinus, w: Handbuch der Dogmengeschichte, Herder 1970, Band III, Faszikel $3 b, 55$.

" K. Baus - E. Ewig, Die Reichskirche nach Konstantin dem Grossen, w: Handbuch der Kirchengeschichte, Herder 1973, Band II/1, 282; 311; 346.

7 J. Dariélou - H. I. Marrou, Nouvelle Histoire de l'Eglise, Paris 1963.

s Wszystko, co autor ma do powiedzenia, ujmuje w dwa zdania: ,De l'Ambrosiaster, il n'y a rien de particulier à dire. Son commenttaire sur saint Paul souligne peu les passages relatifs au corps mystique". E. Mersch, Le Corps mystique du Christ, Paris 1936, t. II 95 (przyp. 2).

${ }^{9}$ H. Rhaner, Symbole der Kirche. Die Ekklesiologie der Väter, Salzburg 1964. Ambrozjastra wspomina tylko dwa razy: s. 446; s. 39 (przypis).

10 C. Martini, Ambrosiaster. De auctore, operibus, theologia, Romae 1944, 119$-123$

11 W. Mundle, Die Exegese der paulinischen Briefe im Kommentar des Ambrosiaster, Marburg 1919, 54-70.

12 O. Heggelbacher, Vom römischen zum christlischen Recht. Iuristische Elemente in den Schriften des sog. Ambrosiaster, Freiburg Schweiz 1959, 95-134. 
I. KOŚCIÓ OD STWORZENIA SWIATA DO WCIELENIA SYNA BOŻEGO

1. Świat duchów

Zrozumienie eklezjologii Ambrozjastra wymaga zapoznania się, przynajmniej w ogólnym zarysie, z jego nauką o stworzeniu. Autor bowiem, podobnie jak większość chrześcijańskich pisarzy starożytnych, przyjmuje preegzystencję Kościoła.

Według Ambrozjastra istniejąca obecnie rzeczywistość została stworzona w dwu etapach. W pierwszym Pan Bóg stworzył wspaniały świat duchów, w drugim - świat widzialny, ziemię i ludzi. Aktu stworzenia, zarówno w jednym jak i drugim wypadku, dokonał Bóg przez swego Jednorodzonego Syna ${ }^{13}$.

Zdaniem autora olbrzymia rzesza duchów niebieskich, czyli istot żywych, obdarzonych rozumem i wolną wolą, już samym aktem stwórczym została przez Boga podzielona na pewne chóry ${ }^{14}$. Każdy z nich składał się z wielkiej liczby jednostek, a różnił się od pozostałych naturą i wykonywanymi funkcjami 15. Podstawą podziału była różnica natur. Natura bowiem, a mówiąc ściślej jej doskonałość, decydowała o miejscu danego chóru w hierarchii duchów niebiańskich ${ }^{16}$. Cherubiny i serafiny, czyli duchy posiadające naturę bardzo doskonała, Ambrozjaster ustawia w najbliższym sąsiedztwie Tronu Bożego. Innych: władze, księstwo, moce układa stopniowo coraz niżej, aż do aniołów zwykłych (bez tytułu), którym zda się wyznaczać miejsce nad firmamentem, oddzielającym niebo od ziemi ${ }^{17}$.

Mimo tak zasadniczej różnicy, wynikającej z samej natury, wszystkie chóry duchów niebiańskich od samego początku tworzyły jedną zwartą całość. Tak bowiem całe chóry aniołów jak i poszczególne jednostki, jako byty stworzone, a więc i ograniczone, nie mogły być samowystarczalne. Z ustanowienia zatem Bożego, zgodnie ze swym przeznaczeniem, miały pomagać innym duchom i równocześnie korzystać z ich pomocy. I właśnie ta wzajemna pomoc i współpraca - zdaniem autora - zespalała cały świat duchów, czyniąc go jakby jednym organizmem, jakby jednym ciałem ${ }^{18}$.

Ambrozjaster nie waha się przed użyciem terminu „Ciało” (Corpus) w odniesieniu do całego świata duchów, wręcz przeciwnie stosuje go

13 Zdaniem Ambrozjastra Bóg Ojciec odwiecznie zrodził Syna właśnie w tym celu, by przez Niego stworzyć świat. Gruntowniej omawia to zagadnienie M. Michalski w rozprawie: Problem autorstwa tzw. Ambrozjastra w świetle jego nauki chrystologicznej, Kraków 1948, 49.

14 Comm. Ef 4, 16 (2), 102.

15 Tamże.

16 Q. 1, 1, 13.

17 Dokładniej analizuje to zagadnienie E. Stanula w artykule: Aniołowie oraz ich upadek wedtug Ambrozjastra. ,Studia Theol. Vars”., 13 (1975) $\mathrm{nr} 2,107$.

18 Q. 47, 1, 9; Comm. Ef 4, 16 (2), 102. 
często $i$ to $z$ dużym upodobaniem. Termin ten pozwala mu bowiem nie tylko traktować poszczególne stworzenia czy całe ich grupy jako członki jednej wielkiej całości, ale przede wszystkim pozwala mu ukazać organiczną więź stworzenia z Synem Bożym jako Głową. W komentarzu do Ef 1, 22 pisze wyraźnie: „Ojciec wszelkie stworzenie poddał Synowi, aby - ponieważ wszystko przez Niego uczynił - On sam (Syn) był Głową i Panem wszystkiego. Wtedy poddał Mu wszystko, kiedy Go zrodził przed wszystkim, aby przez Niego stało się to, czego nie było" ${ }^{19}$, a w komentarzu do Kolosan pisze jasno: „,stworzenie jest Jego (Syna) Ciałem" 20.

Przy tej okazjị autor bardzo mocno akcentuje jeden szczegół. Aniołowie, chociaż zostali stworzeni przez Syna Bożego, to jednak Go nie znali ${ }^{21}$. A nie mogli Go znać z tej prostej racji, że wtedy jeszcze istnienie tajemnicy Osób Bożych nie było objawione. Niemniej Syn Boży, chociaż nie znany, faktycznie od samego początku był Głową wszelkiego stworzenia. Autor, dla uzasadnienia tego twierdzenia, przytacza dwa argumenty. Po pierwsze, każde stworzenie zaistniało przez Niego ${ }^{22}$. Po drugie, podobnie jak głowa utrzymuje przy życiu całe ciało, tak Syn Boży utrzymuje przy życiu wszelkie stworzenie ${ }^{23}$.

Ten drugi argument domaga się bliższego wyjaśnienia. Wprawdzie ani w Komentarzu, ani w Kwestiach autor nie określa wyraźnie natury owego życia, jakim Syn Boży (Głowa) obdarza całe Ciało, ale jedno jest dla niego pewne. Stworzenia, które świadomie i dobrowolnie utrzymują kontakt z Bogiem, uznając tylko Jego władzę, uczestniczą w życiu Głowy, są żywymi członkami Ciała Syna Bożego. Natomiast duchy zrywające więź z Bogiem, a więc i z Głową, tracą życie i stają się członkami martwymi ${ }^{24}$.

Tajemnica życia, które z Głowy promieniuje na całe Ciało, stanowi bardzo istotny element eklezjologii Ambrozjastra. To życie bowiem jest najważniejszym czynnikiem, decydującym o jedności całego Ciała. Prawdą jest - jak powiedzieliśmy wyżej - że poszczególne członki Ciała Syna Bożego łączy współpraca i wzajemna wymiana usług, ale pierwszym i najważniejszym fundamentem jedności jest unitas professionis ${ }^{25}$, czyli świadome poczucie przynależności do jedynego Boga. Terminem unitas professionis autor bowiem stara się oddać atmosferę zgody, jedności i harmonii, panującą w domu (rzymska familia), gdzie wszyscy -

\footnotetext{
19 Comm. Ef 1, 22, 78.

20 Comm. Col 2, 8 (4), 182; tamże, 2, 18 (2), 189.

21 Q. 123, 11, 378.

22 Comm. Col 1, 16 (1), 172; tamże, 2, 1 (2), 179.

23. Comm. Col 1, 23 (2), 176; Comm. Ef 5, 29, 118.

24 Comm. Ef 2, 1, 79; Comm. Col 1, 23, 176.

25 Comm. Ef 4, 16 (2), 103.
} 
żona, dzieci, krewni, słudzy, niewolnicy - każdy na swój sposób, uczestniczyli w życiu pana domu, który był głową całej tak pojętej rodziny ${ }^{26}$.

W momencie zaistnienia świata duchów niebiańskich, jeszcze przed stworzeniem świata widzialnego, został zatem stworzony wspaniały dom, wielka Boża Familia. I właśnie ten dom, tę wspaniałą wspólnotę, to Ciało, złożone $\mathrm{z}$ wielu członków, $\mathrm{z}$ których każdy miał inną naturę i każdy składał się z niezliczonej ilości jednostek, autor nazywa Kościołem ${ }^{27}$.

Ponieważ mówiąc o członkach (membra) Kościoła autor ma na uwadze raz poszczególne jednostki, a innym razem całe ich zespoły, posiadające tę samą naturę, powstaje pytanie, czy biorąc pod uwagę to drugie znaczenie można, przynajmniej w przybliżeniu, określić liczbę członków Kościoła przed stworzeniem ludzi, innymi słowy, czy można podać liczbę chórów anielskich?

Jedynym tekstem, który ewentualnie mógłby coś powiedzieć na ten temat, jest wypowiedź autora w kwestii 47-ej. Ambrozjaster komentuje tu slowa Izajasza: ,,zbliży się siedem kobiet do jednego mężczyzny... $(4,1)$ ". Długie alegoryczne wyjaśnienie rozpoczyna od bezdyskusyjnego stwierdzenia: „nie ulega najmniejszej wątpliwości, że przez siedem kobiet jest oznaczonych siedem kościołów; chociaż bowiem jest jeden (Kościół), nazwany jest siedmiorakim, aby jedno Ciało składało się z siedmiorakiej liczby członków. Nie tylko bowiem my (ludzie), lecz i duchy niebiańskie są członkami Kościoła, którego Głową jest Chrystus" 28. Jest faktem, że w tym wypadku alegoryczny wykład podyktowany był tekstem Izajasza, w którym występuje liczba ,siedem”. To zmusza do dużej ostrożności. W alegorii liczby mogą mieć najróżniejsze znaczenie i wcale nie muszą odpowiadać rzeczywistości. Kiedy jednak próbujemy dokładniej policzyć porozrzucane po obu dziełach nazwy, stosowane przez Ambrozjastra w odniesieniu do chórów niebiańskich, okazuje się, że z dużym prawdopodobieństwem można je sprowadzić do liczby sześciu ${ }^{29}$. Siódmy kościół — według cytowanego wyżej fragmentu - tworzą ludzie. Ale o nich za chwilę.

Jeżeli nasze odczytanie Ambrozjastra jest poprawne, to przed stworzeniem ludzi Kościół jako Ciało Syna Bożego składałby się z sześciu chórów anielskich. Ale czy tylko z sześciu? Pytanie jest uzasadnione, ponieważ — według naszego autora — istniał anioł, który pozostałych prze-

26 Próbę ustalenia treści pojęcia ,unitas professionis" podjął E. Stanula, art. cyt., 109.

27 Comm. Ef 1, 22, 78; Q. 47, 1, 91.

28 Q. 47, 1, 90: „In absoluto est septem mulieres septem ecclesias esse significatas; quamvis enim una sit, sed septiformis dicitur, ut corpus unum septemplici numero constet membrorum, non enim nos, sed et superni caelestes ecclesiae membra sunt, cuius caput Christus est".

29 Por. E. Stanula, art. cyt., 108. 
wyższał tak mocą, jak i znajomością tajemnic niebiańskich ${ }^{30}$. Trudno z całą pewnością rozstrzygnąć, czy anioł ów doskonałością swej natury przewyższał pozostałych aniołów, czy też należał do stojących obok Tronu Bożego cherubinów. Jest pewne, że autor nigdzie w sposób wyraźny nie zalicza go do tego chóru, natomiast mocno akcentuje jego wyjątkową potęgę i najwyższą wiedzę tajemnic niebiańskich. Przy innej zaś okazji zaznacza, że poszczególne chóry anielskie różnią się między sobą znajomością Boga ${ }^{31}$. Istnieją zatem dość poważne racje przemawiające za wyodrębnieniem, nawet pod względem natury, tego jednego anioła spośród wszystkich pozostałych. Jakkolwiek by było, właśnie ten jeden z najdoskonalszych aniołów doprowadził cały istniejący Kościól Syna Bożego do wielkiej tragedii. Uniesiony pychą władczą sięgnął po najwyższą władzę ${ }^{32}$. Chciał być pierwszym po Bogu Ojcu ${ }^{33}$. Chciał zostać głową wszystkich pozostałych duchów niebiańskich. Sięnął po przywilej należny wyłącznie Synowi Bożemu - jedynej prawdziwej Głowie całego stworzenia ${ }^{34}$.

W tym momencie nie potrafimy wyminąc dwu wyłaniających się pytań, a mianowicie: na jakiej podstawie Szatan - bo o niego tu chodzi mógł sięgnąc po tak wielką władzę (chciał być głową Kościoła!) i dlaczego, mimo iż nie znał Syna Bożego, autor nazywa go ,uzurpatorem” Jego godności? ${ }^{35}$

Zdaniem Ambrozjastra Szatan jako jeden z najdoskonalszych aniołów miał dość dużo danych, aby pokusić się o sięgnięcie po władzę nad pozostałymi aniołami. Stojąc u szczytu hierarchii duchów niebiańskich należał do grona najgodniejszych sług Boga. Między Stwórcą a sobą nie widział on nikogo innego. $Z$ tej racji nie chciał służyć innym, chciał panować. Autor przy tym bardzo jasno zaznacza, że Szatan nie usuwał Boga, nie miał pretensji, by go uznano za stworzyciela, nawet nie chciał, by aniołowie byli jego własnością. Nie. Według Ambrozjastra Szatan chciał być pierwszym po Bogu Ojcu, chciał, by wszelkie stworzenie było podporządkowane jego władzy ${ }^{36}$

$\mathrm{Na}$ czym polegał grzech diabła? Zdaniem Ambrozjastra Szatan zniszczył harmonię, ową unitas professionis w domu Boga 37. Został stworzony jako ,członek", miał zatem, z woli Stwórcy, pomagać innym i z nimi współpracować, a nie panować nad nimi. Istota jego grzechu

30 Q. 2, 2, 18.

31 Q. 1, 1, 13.

3. Q. 98, 1, 187.

Q. $113,5,301$.

34 Q. 113, 7, 302: „Caput enim et principium voluit esse ceterorum, quod non ei debeatur, sed salvatori".

35 Q. 113, 6, 301; Comm. 1 Cor 11, 7 (2), 122.

36 Comm. Rom 1, 32, 55; Q. 113, 5, 301 .

37 Comm. Ef 4, 16, 103. 
tkwiła jednak głębiej. Szatan, chcąc być panem wszelkiego stworzenia, sięgnął po atrybut boski, przez co zlekceważył jedynego Pana - Boga ${ }^{38}$.

Jeśli chodzi o „uzurpację” godności Syna Bożego to trzeba pamiętać, że autor $\mathrm{w}$ swoim Komentarzu ani na moment nie zawaha się nazwać Syna Bożego Archaniołem. Wyjaśniając pierwszy list do Tessaloniczan, kreśląc wizję czasów eschatologicznych, w ostatniej decydującej walce ustawia naprzeciw siebie dwu aniołów: upadłego - Szatana i Archaniola - Jezusa Chrystusa ${ }^{39}$. Cały problem poddamy szczegółowej analizie pod koniec naszych rozważań. Tu jedynie zaznaczamy, że zaliczenie przez Ambrozjastra Syna Bożego, a. więc prawdziwej Głowy Kościoła, do Archaniołów, łączy niezwykle silnie jego eklezjologię $\mathrm{z}$ angelologia i że w koncepcji teologicznej naszego autora rywalizacja Szatana z Synem Bożym posiada głębokie uzasadnienie.

Wróćmy jednak do naszego tematu. Wystąienie Szatana - zdaniem Ambrozjastra - doprowadziło do rozłamu w świecie duchów. Znaczna ich część faktycznie opowiedziała się po stronie uzurpatora ${ }^{40}$. Inni nie uznali jego roszczeń i pozostali wierni Bogu. Tak skończył się pierwszy etap dziejów Kościoła. Jedno Ciało Syna Bożego uległo rozdarciu. Część członków żyła nadal, pozostając w łączności z Bogiem, część jednak która autor najczęściej określa jako „księstwa” i „moce” 41 — zrywając łączność z Bogiem, a więc i z Głową, stała się obumarła. Autor nie precyzuje, kto ze świata duchów opowiedział się za uzurpatorem. Nie wiadomo, czy upadek był połączony z odpadnięciem od fiłowy całych chórów, tzn. wszystkich aniołów posiadających taką samą naturę, czy też rozpad ciała oparty był na decyzji jednostek i każdy z chórów miał takich, co odpadli i takich, co pozostali wierni. Za pierwszą możliwościa przemawiałyby nazwy — „księstwa” i „moce”, których autor systematycznie używa na określenie, ,satelitów diabła”. Za drugą, wielki szacunek dla wolnej decyzji każdej rozumnej istoty.

Właśnie to wielkie poszanowanie przez Boga wolnej woli, w która wyposażył stworzenia - według Ambrozjastra - nie pozwoliło Stwórcy na użycie siły, celem odebrania Szatanowi władzy nad odpadłymi aniołami. Wprawdzie wierni aniołowie sami rozprawili się $z$ apostatą i wyrzucili go $z$ nieba, strącając na ziemię ${ }^{42}$, niemniej Szatan nadal pozostał przywódcą tych duchów, które się za nim opowiedziały. W tej sytuacji Bóg - zdaniem autora - postanowił przywieść do opamiętania tych, którzy zostali uwiedzeni przez diabła, a jego samego upokorzyé, posłu-

38 Comm. 1 Cor $11,7(2), 122$.

39 Comm. 1 Thes. 4, 18 (2), 227; E. Stanula wyjaśnienia, w jakim sensie można mówić o uzurpacji godności Syna Bożego. Art. cyt., 113.

${ }^{40}$ Q. 2, 2, 17.

41 Comm. Col 2, 14 (2), 185.

42 Q. 113, 4, 300. 
gując się zupełnie nowym, dotychczas nieistniejącym stworzeniem człowiekiem.

\section{Swiat ludzi}

Ambrozjaster bardzo wyraźnie łączy powstanie świata materialnego z upadkiem aniołów. „Materia została stworzona, aby zniweczyć (...) usiłowanie diabła" ${ }^{43}$. Szczególnie jednak chodzi mu nie tyle o materię, ile o człowieka. Na jego bowiem przykładzie Szatan i świat duchów miał poznać prawdę ${ }^{44}$.

Człowiek jako istota rozumna, $\mathrm{z}$ racji swego połączenia $\mathrm{z}$ ciałem, a więc $\mathrm{z}$ materią, pod względem natury był tworem najmniej doskonałym. Dlatego też $w$ ich hierarchii znalazł się na samym dole. Można z pełnym uzasadnieniem powiedzieć, że - zdaniem autora - Bóg, stwarzając przez swego Syna rodzaj ludzki, powiększył istniejące już Jego Ciało - Kościół o nowy członek ${ }^{45}$. Członek ten przez to, że miał być wzorcowym, od samego początku znalazł się w centrum uwagi całego stworzenia. Odtąd losy całego Kościoła będą całkowicie uzależnione od losów tego jednego członka, czyli od Kościoła złożonego z ludzi.

Chodzącym po raju człowiekiem interesował się przede wszystkim Szatan. Wiedział on bowiem, że nowe stworzenie Boże, któremu nadano imię Adam, ma być jego oskarżycielem ${ }^{46}$. Postanowił zatem podstępnie podporządkować go swojej władzy. Podstęp się udał. Człowiek, otrzymawszy od Boga wolną wolę, miał prawo wyboru. Poszedł za propozycja Szatana. Zlekceważył Boże przykazanie, opuścił Stwórcę i stał się niewolnikiem diabła. Tym samym Szatan odniósł następne zwycięstwo. Podporządkował sobie jeszcze jeden członek Kościoła - rodzaj ludzki.

Ambrozjaster wyraźnie stwierdza, że ,w Adamie wszyscy zgrzeszyli" 47 i że z tej racji diabeł nad. wszystkimi ludźmi posiada władzę. Wprowadza jednak wyraźne rozróżnienie. Adam - jego zdaniem - nie tylko przekazał swemu potomstwu grzech pierworodny, ale przekazał mu również wzór, dał mu przykład grzeszenia. To rozróżnienie pozwala autorowi sprecyzować następne twierdzenie. Chociaż wszyscy ludzie rodzą się $w$ grzechu $i \mathrm{z}$ tej racji są niewolnikami Szatana, to jednak nie wszyscy w swoim życiu naśladują postępowanie swego ojca - Adama ${ }^{48}$. Z tej też racji nie nad wszystkimi Szatan posiada tak wielką wladzę jak nad Adamem.

43 Q. 2, 3, 18.

44 Tamże.

45 Taki obraz uzyskujemy zestawiając kwestię 47, gdzie jest mowa o siedmiu Kościołach w jednym Kościele, z kwestią 3, w której autor odpowiada na pytanie: Dlaczego Bóg stworzył świat?

46 Q. 2, 4, 19.

47 Comm. Rom 5, 12 (3), 165.

48 Comm. Rom 5, 14 (2), 171. 
Można powiedzieć, że świat ludzi, czyli Kościół na ziemi stworzony na podobieństwo świata duchów ${ }^{49}$, w jakiejś mierze upodobnił się do niego i pod względem rozpadu. Na ziemi, podobnie jak w świecie duchów, pewni ludzie pozostali wierni Bogu. Część ludzi nie upadła tak nisko jak Adam. Ambrozjaster mówi o tym jasno: „chrześcijaństwo było zawsze. Wszyscy przodkowie, którzy tylko mieli wiarę w jednego Boga, którą głosił Zbawiciel, słusznie powinni być nazwani chrześcijanami" 50 . Jednak grono wiernych ludzi, w porównaniu z tymi, którzy obrazili Boga "na podobieństwo Adama" - zdaniem autora - jest bardzo nieliczne ${ }^{51}$.

Pan Bóg widząc zniszczone drugie swoje dzieło, postanawia w pierwszej kolejnoścì wyzwolić spod władzy Szatana rodzaj ludzki, czyli Kościól istniejący na ziemi. W tym celu spośród potomków Adama wybiera człowieka, który w życiu swoim nie naśladował grzesznego postępowania swego ojca, który wierzył w Boga i nigdy Go nie zlekceważył. Tego człowieka Bóg czyni ojcem wybranego narodu.

Według Ambrozjastra Abraham, bo o niego tu chodzi, jest obok Adama głównym bohaterem historii rodzaju ludzkiego, a więc i całego Kościoła. W nim bowiem rodzaj ludzki został odnowiony. Podobnie jak Adam dał ludziom przykład grzeszenia, Abraham dał im przykład zawierzenia Bogu 52. Z tej racji Abraham jest ojcem w podwójnym znaczeniu. Co do ciała jest ojcem narodu wybranego - Izraela, co do ducha - jest ojcem wszystkich ludzi wierzących. Potomkowie Abrahama stanowią tę cząstkę rodzaju ludzkiego, która skłania głowę przed Bogiem i - mimo obciążeń grzechem Adama - uznaje jedyną władzę Boga nad sobą. Izrael to naród wybrany, to adoptowany przez Boga lud, lud Boży (populus dei; plebs dei) — Kościół 53 .

Zarówno w Komentarzu jak i w Kwestiach Ambrozjaster poświęca bardzo dużo uwagi losom Izraela. Komentując pewne rozdziały listu do Rzymian, w obszernych wywodach próbuje możliwie jak najdokładniej przeanalizować wielkość powołania Narodu Wybranego, tragedię jego odrzucenia i zapowiedź powrotu do Boga. Według niego naród ten spełnił i dotychczas spełnia jakąś tajemniczą rolę w historii całego Kościoła. Izrael bowiem, mimo niewierności, zawsze stanowił integralną część Kościoła ${ }^{54}$. Wynika to nie tylko z powołania, którym Bóg go obdarzył, ale i $z$ wierności pewnych jego przedstawicieli. Właśnie $w$ nim, w Narodzie Wybranym, obok wielkiej liczby odchodzących od Boga zawsze żyli tacy, którzy niezłomnie trwali przy Stwórcy.

49 Comm. 1 Cor 6, 2 (1n), 59.

50 Q. 3, 4, $23 \mathrm{n}$.

51 Comm. Rom 5, 14, 173; 5, 12 (4), 165.

52 Q. 108, 4, 254; Q. 117, 6, 354.

53 Comm. Rom 9, 25, 331; 16, 23, 493.

54 Comm. Ef 2, 21, 86. 
W świetle dotychczasowych wywodów wyłania się niezwykle ważne pytanie: czy człowiek po upadku, w imię swej wolności, mógł sam wrócić do Boga. Odpowiedź autora jest jednoznaczna. W żadnym wypadku nie mógł. Przez grzech człowiek stał się własnością Szatana. Znalazł się w niewoli. Nawet do garstki sprawiedliwych, którzy nigdy nie popełnili grzechu ,na podobieństwo Adama”, Szatan miał prawo w oparciu o grzech, w jakim się urodzili. Stąd też po śmierci wszyscy trafiali do otchłani i tylko w zależności od wielkości swych grzechów osobistych zajmowali tam niższe lub wyższe piętra ${ }^{55}$.

Identyczne pytanie można postawić pod adresem upadłych aniołów. Czy satelici diabła, w każdym momencie, kiedy tylko zechcieli, mogli aktem swej wolnej woli opuścić Szatana i powrócić dó Boga? Odpowiedź Ambrozjastra jest również negatywna. Trzeba jednak przyznać, że autor w tym wypadku natrafia na dużą trudność. Ceniąc bardzo wysoko wolną wolę wielokrotnie zaznacza, że o łączności z Bogiem decyduje wybór danego stworzenia. Kiedy jednak zastanawia się nad tym problemem szczegółowo, odpowiedź jego jest jasna. Zarówno ludzie jak i duchy niebiańskie potrzebowały Chrystusa. Bez Jego pomocy nie potrafiłyby zgładzić ,swojej hańby” 56.

Ciekawy jest tekst kwestii 47-ej, w którym autor podejmuje właśnie ten problem. Wynika z niego, że cały Kościól, czyli wszelkie stworzenie, a więc i wszystkie chóry niebiańskie - wierne i niewierne - potrzebowały Chrystusa, że na wszystkich spoczywała jakaś ,hańba” 57. Autor bliżej tego nie precyzuje. Można by tu ewentualnie dopatrzyć się jakiegoś podobieństwa między ludzkością grzeszną jako całość i, rozdartym przez grzech Szatana, światem aniolów, który czeka na zjednoczenie. $\mathrm{Z}$ innych wypowiedzi zda się jednak wynikać, że duchy wierne Bogu potrzebowały Chrystusa nie tyle dla pozbycia się jakiejś „hańby”, ile raczej dla poznania swej Głowy ${ }^{58}$.

W tej beznadziejnej sytuacji w dzieje Kościoła wkracza Syn Boży. Rodzi się jako człowiek w Izraelu, w tej garstce, która pozostała wierna Bogu. Moment Wcielenia stanowi punkt zwrotny w historii całego Kościoła. Dotychczas - według Ambrozjastra - stworzenie nic o istnieniu tajemnicy Trójcy Św. nie wiedziało. Teraz, skoro Syn Boży stał się -człowiekiem, tajemnica Boga zostanie udostępniona wszelkiemu stworzeniu ${ }^{59}$. Zbałamucone duchy niebiańskie i grzeszni ludzie, poznając w Chrystusie, kto jest prawdziwą Glową wszelkiego stworzenia, przy

55 Comm. Rom 5, 14, 173.

56 Całą kwestię 47 autor poświęca udowodnieniu tej prawdy.

57 Q. 47, 1, 90.

58 Q. 47, 4, 93.

59 Dla scharakteryzowania dzieła dokonanego przez Chrystusa autor najczéściej posługuje się następującymi terminami: ,recreare, reformare, reaedificare, regenerare, restaurare, redimere, vivificare". 
Jego pomocy będą opuszczały uzurpatora i wracały do Boga. Chrystus, wcielony Syn Boży, zjednoczy swe rozdarte Ciało, przywróci obumarłym członkom życie, odbuduje zniszczony przez Szatana Kościół.

Z Wcieleniem Syna Bożego rozpoczyna się zatem - według Ambrozjastra - nowy etap w historii Kościoła. Nie będzie w nim już tragedii na miarę upadku diabła czy Adama. Będzie to etap odbudowy i doskonalenia, aż do pełnego powrotu wszelkiego stworzenia do Boga. Będzie to - jego zdaniem - powrót tym wspanialszy, że całe odnowione Ciało Chrystusa zostanie napełnione znajomością Boga i Jego Tajemnicy. Jakie konkretne formy przybierze zarówno zwycięska walka z Szatanem, jak i stopniowe doskonalenie Kościoła - oto pytanie, które będzie wyznaczało kierunek naszym dalszym poszukiwaniom.

\section{KOSCIOE OD WCIELENIA SYNA BOZEGO DO KOÑCA ŚWIATA}

\section{A. Chrystus podejmuje dzieio odbudowy Kościoła}

Ambrozjaster zasadniczo nie wspomina o zakładaniu Kościoła przez Jezusa Chrystusa. Nas, katolików XX wieku, przyzwyczajonych do ujmowania historii Kościoła od Wcielenia, a mówiąc ściślej od Zesłania Ducha Sw., takie milczenie $w$ pewnym stopniu zdumiewa. A jednak, w świetle tego, co powiedzieliśmy wyżej, musimy przyznać, że w tym wypadku postawa naszego autora jest konsekwentna.

Skoro - jego zdaniem - Kościół jest tak stary, jak stare jest dzieł̣o stworzenia, to Syn Boży, stając się człowiekiem, miał do czynienia już $z$ istniejącym Kościołem. Jego zatem interwencja nie polegała na stworzeniu czegoś zupełnie nowego, ale jedynie na odbudowaniu tego, co zostało przez Szatana zniszczone. Chrystus nawet nie stwarza nowych członków Kościoła, ale jedynie przywraca życie tym, które przez grzech były jakby obumarłe. Wprawdzie autor wielokrotnie mówi o ,nowym Ciele Chrystusa" "60, ale czyni to nie w sensie stworzenia czegoś, co dotychczas $\mathrm{w}$ ogóle nie istniało, lecz $\mathrm{w}$ sensie odrodzenia tego, co było obumarłe. Komentując Kol 1, 18 Ambrozjaster pisze: „Chrystus przed wiekami narodził się z Boga, aby stworzyć wszystko, czego nie było, potem zaś narodził się wziąwszy ciało z Dziewicy, aby zniszczyć grzech, który wszedł na świat z dziewicy Ewy. Narodziwszy się i poniósłszy śmierć zmartwychwstał i to, co przedtem uczynił, później po raz drugi odtworzył, ponieważ przez grzech było jakby umarłe" 61 .

Według autora nikt nie mógł tego dokonać, jedynie Syn Boży ${ }^{62}$. Jego dzieło zostało zniszczone i On jeden miał prawo je odbudować. Przy-

te Comm. Ef 2, 16, 84; Comm. Filip 2, 1 (1), 138.

61 Comm. Col 1, 18 (2), 173.

62 Comm. Col 1, 18 (1), 173. 
wrócenie pierwotnej doskonałości zniszczonemu Kościołowi było jednak nierozerwalnie złączone z pokonaniem Szatana. Skoro - według Ambrozjastra - stworzenie człowieka miało posłużyć Bogu do pognębienia diabła, to w o wiele większym stopniu, według niego, taki właśnie cel posiadało Wcielenie Syna Bożego ${ }^{63}$. Nie był to jednak cel wyłączny. W kwestii 113-tej czytamy, że "Chrystus przyszedł nie tylko po to, by poskromić diabła, ale również, by siebie samego objawić całemu stworzeniu..." 64 .

W odniesieniu do Kościoła pokonanie Szatana miało prowadzić z jednej strony do odebrania mu władzy nad obumarłymi członkami Chrystusowego Ciała, czyli nad ludzkością i upadłymi aniołami, z drugiej, do powtórnego połączenia tych członków z Bogiem. Podobnie podwójny cel miało pogłębienie $w$ stworzeniu znajomości Boga, czyli objawienie tajemnicy Trójcy Świętej. Było ono bowiem środkiem poskromienia Szatana, a równocześnie narzędziem doprowadzenia całego Kościoła, czyli Chrystusowego Ciała, do doskonałości większej niż ta, jaką posiadało ono przed upadkiem. Oczywiście przy takim podejściu pokonanie Szatana i objawienie tajemnicy Boga w koncepcji naszego autora jest tak mocno ze sobą związane, że w żaden sposób nie da się mówić o jednym, nie dotykając drugiego.

Dla tej części Kościoła, którą stanowił rodzaj ludzki, Wcielenie Syna Bożego miało - według Ambrozjastra - jeszcze dwie dodatkowe konsekwencje. Chrystus bowiem nie po to wykupił ludzi z mocy Szatana, by z kolei uczynić ich własnymi niewolnikami, ale by ich wyzwolił (manumittere) ${ }^{65}$, a nawet umożliwić swemu Ojcu ich adopcję ${ }^{66}$. Odtąd ta cząstka Chrystusowego Ciała, którą stanowili ludzie, obdarzona zostanie nową, dotychczas zupełnie nieznaną godnością, mianowicie godnością adoptowanych dzieci Boga. Druga konsekwencja dotyczyła kontynuacji rozpoczętego przez Chrystusa dzieła objawienia. Nie wszystkie stworzenia mogły poznać tajemnicę Boga w czasie pobytu Chrystusa na ziemi, a mówiąc ściślej, w okresie między Jego Wcieleniem a Wniebowstąpieniem. Zwłaszcza nie mogli Go poznać ludzie, którzy urodzili się dopiero po tych wydarzeniach. Celem kontynuowania rozpoczętego dzieła objawienia Chrystus w czasie ziemskiej działalności wybrał i powołał uczniów ${ }^{67}$. Oni mieli udostępnić innym znajomość tajemnicy Boga.

Możemy zatem powiedzieć, że Ambrozjaster rozważa cztery zasadnicze skutki Wcielenia Syna Bożego:

1) odebranie Szatanowi prawa panowania nad ludźmi,

63 Comm. 1 Cor 15, 57, 187.

${ }_{64}$ Q. 113, 6, 301; Comm. Ef 1, 9 (1), 74.

65 Comm. Ef 1, 7, 73.

66 Comm. Gal 1, 4 (2), 7.

6. Q. 100, 2, 192 . 
2) objawienie całemu Kościołowi, tzn. ludziom i wszystkim chórom anielskim, tajemnicy Trójcy świętej,

3) umożliwienie Ojcu Niebieskiemu adopcji ludzi wierzących,

4) wybranie i powołanie pewnych ludzi do kontynuowania rozpoczętego przez Syna Bożego dzieła objawienia Tajemnicy Osób Bożych.

Zmierzając do możliwie pełnego naszkicowania nauki Ambrozjastra o Kościele, musimy obecnie nad każdym z tych punktów nieco głębiej się zastanowić.

\section{Szatan traci prawo panowania nad ludźmi}

$\mathrm{Na}$ początku zaznaczyliśmy, że Szatan, doprowadzając Adama do upadku, podporządkował sobie cały rodzaj ludzki. Obecnie, chcąc dokładniej naświetlić sposób, w jaki Chrystus odebrał Szatanowi prawo do człowieka, a więc do tej części Kościoła, którą stanowią ludzie, musimy nieco szerzej rozważyć całą sytuację, w jakiej znalazł się zarówno Szatan, jak i człowiek po grzechu rajskim.

Zdaniem Ambrozjastra człowiek na skutek grzechu stracił przywilej nieśmiertelności. Stwórca wydał wówczas wyrok: ,z ziemi jesteś i do ziemi powrócisz ( $\mathrm{Rdz} 3,19)$ ". Przez to skazał każdego człowieka na śmierć. Mocą tego wyroku ciało człowieka z chwilą śmierci rozsypywało się $w$ proch (wracało do ziemi), a dusza wędrowała do podziemia (ad inferos) ${ }^{68}$. Tak pojętą śmierć, która $w$ zasadzie utożsamia się $z$ niemożnością zmartwychwstania, autor nazywa ,śmiercią pierwszą" (mors primai) ${ }^{69}$.

Sama otchłań (inferi), do której wędrowała dusza każdego zmarłego człowieka, posiadała - zdaniem Ambrozjastra - aż trzy piętra. Wejście do niej było następstwem grzechu dziedzicżnego, natomiast przydział pięter dokonywał się na podstawie grzechów osobistych. I tak, dusze ludzi, którzy nie popełnili grzechu ,na podobienstwo przestępstwa Adama”, a więc nie zlekceważyli Boga, dusze ludzi sprawiedliwych (iusti) przebywały na najwyższym piętrze, wyczekując obiecanego Zbawiciela ${ }^{70}$. Do tych ludzi należał przede wszystkim Abraham i ci, którzy na jego podobieństwo zawierzyli Bogu. Grzesznicy (peccatores) zajmowali piętro środkowe, gdzie paleni ogniem cierpieli męki. Najniżej znajdowaly się dusze bezbożnych (impii), którzy mieli na sumieniu grzechy najcięższe, zwłaszcza niewiarę. Ich dręczył okrutny żar ${ }^{71}$.

is Comm. Rom 5, 12 (3), 165

63 Comm. Rom 5, 14 (3a), 173.

ii) Tamże.

71 Tamże. 
Między piętrem najwyższym, a dwoma pozostałymi autor dostrzega niezwykle głęboką przepaść 72. Podkreśla przy tym, że nie chodzi tu tylko o różnicę w lepszym lub gorszym losie jednych i drugich. Dzieli ich coś więcej - przepaść następnej śmierci! Ambrozjaster uważa, że grzesznicy (peccatores) i bezbożni (impii) umierają ,śmiercią drugą" (mors secunda) ${ }^{73}$. Sprawiedliwi natomiast taką śmiercią nie zostają dotkniẹci. Wprawdzie z wielu wypowiedzi wynikałoby, że ,śmierć druga" to synonim kary ${ }^{74}$, niemniej autor wyraźnie zaznacza, że grzesznik odwracajęe się od Boga traci życie, staje się martwy ${ }^{75}$. Stąd też należy raczej przyjąć, że terminem „śmieré druga" autor obejmuje zarówno brak życia, które posiadają ludzie pozostający w kontakcie z Bogiem, jak i karę za jego utratę.

Przy tej okazji Ambrozjaster zwraca mocno uwage jeszcze na jeden moment. Chodzi o stosunek do Szatana. Grzesznicy i bezbożni przez to, że swymi czynami naśladowali Szatana, stali się jego synami (filii diciboli), a synostwo to równało się niewoli ${ }^{76}$. Autor wielokrotnie podkreśla, że grzesznicy są niewolnikami Szatana. Sprawiedliwi (iusti), ponieważ nigdy w swoich czynach nie naśladowali Szatana, nigdy również nie byli jego niewolnikami. Byli sługami Boga. Władza Szatana wobec nich ograniczała się tylko do uniemożliwienia im opuszczenia otchlani 77 .

W tej sytuacji, aby pokonać Szatana, trzeba było - zdaniem autora - zabrać i zniszczyć dekret, mocą którego diabeł przetrzymywal dusze w otchłani oraz wykupić jego niewolników, do których miał pełne prawo. Syn Boży, wykonując wolę Ojca Niebieskiego, postanawia dokonać i jednego i drugiego. Aby jednak swój plan mógł zrealizować, musiał dostać się do otchłani, tam bowiem - według wyobrażenia autora - diabeł przechowywał dekret (cirografum, decretum). Jedyna jednak bramą, która wiedzie do otchłani, jest śmierć ${ }^{78}$. Chcąc się zatem tam dostać, trzeba umrzeć.

Syn Boży, z natury nieśmiertelny, nie miał prawa wejścia do otchłani, dlatego posłużył się podstępem. Zstạpił na ziemię i stał się człowiekiem. Ponieważ zaś do momentu Wcielenia żadne stworzenie kompletnie nie o istnieniu Syna Bożego nie wiedziało ${ }^{79}$, przeto i Szatan, mając przed sobą narodzonego z Marii Jezusa, chociaż dobrze zdawał sobie sprawę z tego, że ma do czynienia z obiecanym przez Boga Mesjaszem, nie przy-

¿2 Tamże.

.3 Comm. Rom 5, 12 (4), 165.

it Comm. Rom 4, 23 (2), 151.

i5 Comm. Ef 2, 1, 79.

76 Comm. Rom 8, 14, 273.

it Autor mówiąc o sprawiedliwych w otchłani zaznacza, że przebywali oni, in superiore quasi in libera" (Comm. Rom 5, 12 (4), 165.

is Q. 83, 3, 141.

${ }_{79}$ Comm. 1 Cor 2, 8 (3), 25; Comm. Rom 2, 22, 85. 
puszczał nawet, by Ten posiadał godność Boską. Nie wiedział również, że On nie posiada żadnego grzechu. Traktując Go jako jednego z potomków Adama, mocą otrzymanego od Boga wyroku rajskiego, „ukłuł Go żądłem śmierci" i wprowadził do otchłani ${ }^{80}$. Autor zdaje sobie sprawę $z$ tego, że w tym wypadku Bóg posłużył się podstępem ${ }^{81}$. Nie widzi w tym jednak nic złego, względnie ubliżającego Stwórcy. Taktykę podstępu pierwszy zastosował Szatan. W raju on przez węża uwiódł człowieka. W tej sytuacji podstęp zastosowany przez Boga Ambrozjaster traktuje tylko jako gest sprawiedliwości ${ }^{82}$

Szatan, mordując na krzyżu człowieka, do którego nie miał najmniejszego prawa, do dwu swoich grzechów - buntu w niebie i uwiedzenia Adama - dodaje trzeci, najcięższy ${ }^{83}$. Tym razem staje bezpośrednio przed Chrystusem w pozycji oskarżonego. Jemu bowiem zupełnie bezprawnie odebrał życie. Cena zaś tego życia była tak wielka, że wystarczyła w zupełności jako okup za wszystkich grzeszników, czyli dotychczasowych niewolników Szatana ${ }^{84}$.

Swoją bezgrzeszność — zdaniem autora - Jezus objawia dopiero w otchłani. Szatan czując się winnym, widząc, że nie posiada żadnej władzy nad Chrystusem, nie ma odwagi sprzeciwić się Jego decyzjom ${ }^{85}$. Chrystus zaś, przez swe Zmartwychwstanie, zabiera i niszczy dekret Boży, mocą którego Szatan przetrzymywał ludzi w otchłani, po czym wyprowadza pozostające tam dusze do nieba ${ }^{86}$. Wynika stąd, że prawnie rzecz biorąc, w momencie zejścia Chrystusa do otchłani, Szatan stracił władzę nad człowiekiem. Przy takim ujęciu powstaje jednak pytanie. Jak zatem wytłumaczyć powszechne panowanie śmierci po Zmartwychwstaniu Chrystusa? Autor wyjaśnia, że Bóg nie może cofnąć raz przez siebie wydanego wyroku ${ }^{87}$, a ponieważ ten dotyczył wszystkich ludzi, wszyscy muszą umrzeć. Mocą zaś dokonanego przez Chrystusa dzieła wszyscy zmartwychwstaną i dopiero powszechne zmartwychwstanie będzie definitywnym pokonaniem Szatana.

Ambrozjaster nie ma żadnych wątpliwości co do tego, że Chrystus, wychodząc z otchłani jako pierwszy spośród wszystkich umarłych, uwolnił wszystkich ludzi od ,śmierci pierwszej”, czyli umożliwił im zmartwychwstanie. A jak sprawa przedstawia się z ,śmiercią drugą"? To problem bardziej skomplikowany. Autor jest pewien, że Chrystus zstą-

so Comm. Col 2, 15 (6), 187.

s1 Autor posługuje się obrazem podstępu, jaki stosują walczący wchodząc na teren przeciwnika w przebraniu. Q. 83, 4, 141.

\&2 Comm. Col 2, 13 (4) recens. pr. 186.

83 Comm. Col 2, 13 (3) recens. pr. 185.

84 Q. 83, 3, 141.

85 Comm. Col 2, 13 (3) recens. pr. 185.

s6 Comm. Col 2, $13(2 \mathrm{n}), 185$.

87 Q. 116, 1n, 350. 
pił do otchłani po to, by uwolnić tych, którzy zmarli „śmiercią drugą" 88 . Jest również pewien, że okup, który złożył, objął wszystkich grzeszników i bezbożnych (peccatores et impii) ${ }^{89}$. Ale czy rzeczywiście wszyscy opuścili otchłań? Wypowiedzi autora zdają się wskazywać na to, że w tym wypadku wprowadza on pewne rozróżnienie. Wszyscy (omnes) mieli prawo opuszczenia otchłani ${ }^{90}$, de facto jednak opuścili ją tylko ci, którzy wierzyli w Chrystusa i na Niego czekali ${ }^{91}$. Powstaje zatem pytanie, czy istniejący w otchłani podział na sprawiedliwych (iusti), grzeszników (peccatores) i bezbożnych (impii) w jakiś sposób pokrywał się z podziałem na wierzących i niewierzących w Chrystusa. Odpowiedź nie jest łatwa. Biorąc pod uwagę, wprowadzone przez Ambrozjastra, bardzo jasne rozróżnienie między ,grzesznikiem” a ,bezbożnym” 92, możemy ze stosunkowo dużym prawdopodobieństwem przyjąć, że niewierzącymi są bezbożni (impii), grzesznicy (peccatores) natomiast wierzyli w Chrystusa i wyczekiwali na Jego przyjście ${ }^{93}$.

Warto zaznaczyć, że zejście Chrystusa ad inferos jest tematem, do którego autor bardzo często powraca. Składają się na to dwa ważne powody. Przede wszystkim otchłań jest miejscem, gdzie Szatan przeżyl swoją klęskę, co - zdaniem Ambrozjastra - zasługuje na szczególną uwagę. Można by nawet zaryzykować twierdzenie, że w pewnych wypowiedziach nasz autor jest skłonny przypisywać większe znaczenie zstąpieniu Chrystusa do otchłani, niż samej Jego śmierci ${ }^{94}$. Z drugiej strony we właściwym naświetleniu zejścia do otchłani autor w jakiejś mierze dostrzega klucz do zrozumienia tego, co Pismo św. mówi o powszechnym zmartwychwstaniu, sądzie i o wiecznym losie całej ludzkości. Sprawa wydaje się prosta. W momencie nawiedzenia otchłani przez Chrystusa rozstrzygnęły się losy ludzi żyjących na ziemi przed narodzeniem Zbawiciela. To rozstrzygnięcie w jakiejś mierze rzutuje na rozstrzygnięcie losów całej ludzkości na końcu świata. Te same bowiem kryteria wiara i jej brak - decydować będą o wiecznym zbawieniu i o wiecznym potępieniu $w$ momencie sądu ostatecznego, podobnie jak decydowały o wyjściu $\mathrm{z}$ otchłani lub pozostaniu w niej w chwili zstąpienia Chrystusa ad inferos.

Z punktu widzenia eklezjologii Ambrozjastra, zstapienie Chrystusa do otchłani posiada wielkie znaczenie. Stanowi ono moment przełomowy w dziejach Kościoła. W otchłani bowiem Szatan został pokonany. Praw-

${ }_{88}$ Comm. 2 Cor 5, 15, 234.

89 Q. 83, 3, 141.

90 Appendix Q. 72, - 467.

91 Comm. 1 Cor 1, 18, 13n.

92 Q. 110, 1, 269.

93 Q. $110,17,276$.

9s Autor traktuje śmierć Chrystusa jako konieczny warunek dostania się do otchłani (Q. 83, 3, 141). 
nie rzecz biorąc stracił władzę nad tą częścią Kościoła, którą stanowili ludzie. Dotychczas zazwyczaj Szatan coś dla siebie zyskiwał. W czasie buntu w niebie zyskał część aniołów; w raju - rodzaj ludzki. Natomiast $\mathrm{w}$ spotkaniu $\mathrm{z}$ Chrystusem $\mathrm{w}$ otchłani nie zyskał nic, a bardzo wiele stracił.

\section{Kościól - jako Ciało - poznaje swoją Głowę}

W otchłani Chrystus nie tylko zniszczył dekret, a więc odebrał Szatanowi władzę nad ludźmi, ale również - według Ambrozjastra - objawił tajemnicę Boga. Tam stworzenie dowiedziało się o istnieniu Drugiej Osoby Bożej - Syna Bożego ${ }^{95}$. Przed objawioną tajemnicą Boga stanęły dusze ludzkie, które przebywały $\mathrm{w}$ otchłani, przed nią stanął również Szatan. Poznanie tej tajemnicy zależało jednak od wiary. Jedni ze sprawiedliwym Abrahamem i grzesznym Adamem ${ }^{96}$ uwierzyli i razem z Synem Bożym wstąpili do nieba. Inni razem z Szatanem nie uwierzyli, pozostając nadal w otchłani ${ }^{97}$. Trzeba jednak zaznaczyć, że autor nie podejmuje wprost tego zagadnienia. Woli mówić o wyprowadzeniu dusz z otchłani, niż o poznaniu przez nie Syna Bożego.

$\mathrm{Z}$ otchłani zmartwychwstały i uwielbiony Chrystus, na czele wybawionych ludzi, wkracza do nieba. Zdaniem autora jest to pochód radosny nie tylko dla ludzi, ale i dla aniołów. Widząc bowiem Syna Bożego wstępującego ponad wszystkie niebiosa, świat duchów niebiańskich, po raz pierwszy od chwili stworzenia, dowiaduje się o Jego istnieniu ${ }^{98}$. Dla Kościoła, czyli dla wszystkich stworzeń rozumnych, moment Wniebowstąpienia Syna Bożego to chwila niezwykle uroczysta. Dotychczas Kościól nie znał swojej Głowy. Znał tylko uzurpatora tej godności — Szatana. Dopiero teraz poszczególne członki Kościoła poznają, jak wielką godność diabeł sobie uzurpował ${ }^{99}$. W momencie Wniebowstąpienia Kościół poznaje Tego, przez Którego został stworzony; Tego, Który poskromił Szatana i odebrał mu to, co podstępem sobie przywłaszczył; Tego, Który ożywia członki obumarłe i powtórnie jednoczy je z Bogiem.

Nie trudno zrozumieć, że przy takim podejściu triumfalny pochód wstępującego w niebo Chrystusa nabiera większego znaczenia, niż samo Jego Zmartwychwstanie, chociaż trzeba przynać, że i temu drugiemu wydarzeniu autor przypisuje dużą wagę ${ }^{100}$. Sytuacja jest podobna, jak

95 Poglądy autora, co do momentu objawienia się Syna Bożego nie są w pełni sprecyzowane. W Quaestiones łączy objawienie z chrztem w Jordanie (Q. 54, - 99), natomiast $\mathrm{w}$ Komentarzu pisze, że Syn Boży był nieznany aż do momentu wstąpienia do otchłani (Comm. 1 Cor 2, 8 (3), 25). Biorąc pod uwagę logiczną konstrukcję całości jego nauki, lepiej jest osadzone to drugie ujęcie.

96 Q. 83, 5, 142.

97 Comm. 1 Cor $1,18,14$.

98 Comm. 1 Tim 3, 16, 271.

99 Q. $113,6,301$.

100 Q. 89, 2, 145. 
przy zestawieniu śmierci Chrystusa i Jego zstąpienia do otchłani, gdzie jak pamiętamy - autor ten drugi akt w pewnych momentach mocniej akcentuje niż pierwszy. Takie rozłożenie akcentów wskazywałoby na ścisłe połączenie nauki Ambrozjastra z tematami rozpracowanymi przez judeochrześcijańską apokaliptykę.

\section{Bóg adoptuje człowieka, to znaczy reformuje Kościół}

Ambrozjaster podziela zdanie św. Pawła, co do wielkiego znaczenia Izraela w dziejach Kościoła. Przez wieki bowiem był to ten jeden jedyny naród, który Bóg darzył szczególną miłością. Była to ta cząstka zniszczonej i opanowanej przez Szatana ludzkości, która pozostawała nadal w kontakcie ze Stwórcą. Na ziemi tylko ten lud znał Boga i oddawał Mu cześć. Wszystkie pozostałe narody nie znały Boga i nie utrzymywały z Nim kontaktu.

Przez swoją Śmierć i Zmartwychwstanie Chrystus zniszczył ten podział i przywrócił rodzajowi ludzkiemu jedność. Włączył pogan do swojego ludu 101. Można powiedzieć, że utworzył nowy lud Boży, w którym jest miejsce i na Żyda i na Greka. „Poganie — pisze Ambrozjaster przedtem nie byli ludem Bożym, po odtrąceniu Żydów, dostąpiwszy miłosierdzia, zostali nazwani ludem Bożym; tak, że ci, którzy przedtem nie byli umiłowani, po odtrąceniu Żydów, zostali umiłowani i adoptowani za synów, aby tam, gdzie dotychczas nie było ludu Bożego, zjawili się synowie Boga żywego. Wcześniej bowiem synowie Boży byli tylko w Judei, tzn. w Jerozolimie, gdzie był dom Boga, jak to mówi Psalm 75: 'Bóg znany w Judei', ale już prorok Zachariasz powiedział: 'Zbuduję Jeruzalem we wszystkich narodach', ponieważ gdziekolwiek będą synowie Boga, tam - we wszystkich narodach — będzie i dom Boży, którym jest Kościół" 102.

Analizując ten fragment trzeba pamiętać, że występujący tu termin „synowie Boży” (filii dei) posiada u Ambrozjastra dwa znaczenia. W sensie szerszym odnosi się do Żydów, żyjących przed przyjściem Chrystusa. Izraelitów — według autora — można nazwać „synami bożymi” z racji ich pobożności 103. W sensie ścisłym termin ten odnosi się do członków nowego ludu, złożonego z Żydów i pogan, istniejącego po przyjściu Chrystusa. Ludzie należący do odnowionego Kościoła są ,synami Bożymi" nie na podstawie swej pobożności, ale z racji otrzymanego od Boga ducha, który stanowi dowód ich faktycznej adopcji104.

\footnotetext{
101 Comm. Ef 2, 20, 86.

102 Comm. Rom 9, 25, 331.

103 Q. 54, - 100.

104 Q. $125,18,390$.
} 
Z punktu widzenia naszych poszukiwań dotykamy tu sprawy niezwykle istotnej. Chrystus nie tylko naprawia w Kościele to, co było zniszczone, nie tylko przywraca rodzajowi ludzkiemu pierwotną doskonałość, ale ulepsza ten człon swojego Ciała, stawia go na wyższym stopniu doskonałości ${ }^{105}$. Istnieje bowiem zasadnicza różnica między nazwaniem kogoś ,synem Bożym” tylko dlatego, że był pobożny, a nazwaniem go w ten sposób dlatego, że faktycznie specjalnym aktem został przez Boga adoptowanym ${ }^{106}$. Warto przy tym pamiętać, że Ambrozjaster mocno podkreśla, iż adopcja dokonana przez Boga jest czynem o wiele doskonalszym od adopcji, $\mathrm{z}$ jaką mamy do czynienia $\mathrm{w}$ stosunkach ludzkich ${ }^{107}$. W perspektywie całego Kościoła, tej wielkiej rodziny Bożej, obejmującej wszelkie rozumne stworzenie, gest adopcji człowieka przez Boga pociąga za sobą niezwykle doniosłe konsekwencje. W momencie Wniebowstąpienia aniołowie dowiedzieli się nie tylko o istnieniu jednorodzonego Syna Bożego, ale dowiedzieli się również o wyniesieniu ludzi do godności adoptowanych dzieci Boga. Zrozumieli, że z punktu widzenia prawnego, człowiek stanął na tej samej płaszczyźnie, co prawdziwy Syn Boga i podobnie jak On, z racji swej adopcji, miał odtąd prawo do dziedziczenia Królestwa Bożego ${ }^{108}$.

Autor bardzo mocno podkreśla fakt pokrewieństwa, jakie od momentu adopcji zachodzi między Synem Bożym, a jego adoptowanymi „,braćmi" ${ }^{109}$. W ten sposób człowiek, który pod względem doskonałości swej nautry zajmował dotychczas najniższe miejsce $w$ hierarchii istot rozumnych, teraz aktem łaski zostaje wyniesiony na jej szczyt. Wszyscy aniołowie - zdaniem Ambrozjastra - nawet najdoskonalsi, patrzą na Boga jako swego Pana, człowiek natomiast, dzięki wyniesieniu do godności dziecka Bożego, widzi w Bogu swego Ojca, a w Chrystusie swego Brata. Od momentu objawienia Syna Bożego Chrystusowe Ciało zostało przemienione. Łaska wyniosła najmniej doskonały członek Kościoła do najwyższej godności i chociaż to jest to samo Ciało, nie jest już Ono takie samo. Jest nowe nie tylko dlatego, że zostało odbudowane, ale i dlatego, że zostało zreformowane. Chrystus zatem jest nie tylko tym, który odbudował, ale i tym, który Kościół zreformował.

W tym momencie musimy na chwilę zatrzymać się przy samym pojęciu Kościoła: Widzimy bowiem, że Ambrozjaster, używając tego samego terminu ecclesia, ma na uwadze dwa różne pojęcia Kościoła. Jednym określa Kościół przed reformą, Kościół istniejący od stworzenia aniołów do Wcielenia Syna Bożego, a mówiąc ściśle, do Jego Wniebo-

105 Q. $123,11,378$

106 Q. $125,19,390$.

107 Tamże.

108 Comm. Ef 1, 19, 77

109 Comm. Rom 2,17, 83; 8, 29, 391. 
wstąpienia. Drugim określa Kościół odbudowywany i zreformowany przez Chrystusa. Jakkolwiek chodzi tu o jeden i ten sam - ujęty w dwóch etapach - Kościół, to jednak, w świetle tego, co powiedzieliśmy wyżej, istnieje między nimi dość wyraźna różnica.

Trzeba przy tym zaznaczyć, że zdecydowana większość wypowiedzi Ambrozjastra odnosi się do Kościoła odbudowywanego i reformowanego przez Chrystusa. Autor w tym Kościele żyje, w nim działa, a więc interesują go przede wszystkim jego losy. Co więcej, ten właśnie Kościół jest - według niego - Kościołem w ścisłym tego słowa znaczeniu. O Kościele sprzed reformy wspomina tylko okazyjnie. Stąd też wszystko, co powiedzieliśmy o pierwszym etapie dziejów Kościoła, jest rekonstrukcją poglądów autora, dokonaną w oparciu o jasne, ale bardzo nieliczne jego wypowiedzi.

4. Chrystus przekazuje Apostołom władzę głoszenia Tajemnicy Trójcy Swiętej

Zdaniem Ambrozjastra Bóg postanowił zbawić świat przez poznanie tajemnicy życia Bożego ${ }^{110}$. Stwórca od samego początku zmierzał do tego, by stworzenia, tak na niebie jak i na ziemi, które zostały zbałamucone przez Szatana, poznały prawdę, odwróciły się od uzurpatora i powtórnie nawiązały łączność z Bogiem. Szatan bowiem wprowadził w błąd wielką ilość stworzeń, i te, zamiast oddawać cześć Bogu, czciły stworzenia 111. Pod wpływem objawienia Tajemnicy Syna Bożego stworzenia te zrozumiały, że cześć boska należy się tylko i wyłącznie Jemu samemu. Porzucały zatem bożki (Szatana i jego satelitów) i skłaniały głowy przez Synem Bożym ${ }^{112}$. W tej sytuacji, w procesie odnowy całego Kościoła, akt poznania Tajemnicy Boga w Trójcy Jedynego odgrywa według Ambrozjastra - zasadniczą rolę. Poznanie to jednak dokonuje się stopniowo. Rozpoczęło się w momencie Wcielenia Syna Bożego i trwać •będzie aż do końca świata. Ten długi etap jest równocześnie okresem stopniowego opuszczenia Szatana i przechodzenia na stronę Chrystusa, innymi słowy, jest okresem stopniowego odradzania obumarłych członków Chrystusowego Ciała - Kościoła ${ }^{113}$.

Chrystus, po wstąpieniu do nieba, nie zajmuje się już bezpośrednio głoszeniem Tajemnicy Boga, pozostawił jednak na ziemi swych uczniów i im zlecił kontynuację tego dzieła ${ }^{114}$. Głównym zatem zadaniem Apostołów było przepowiadanie tajemnicy Chrystusa - głoszenie Jego Bó-

110 Comm. Rom 16, 25 (1n), 495.

111 Q. 113, 7, 302.

112 Comm. 2 Cor 5, 17, 235; Comm. Ef 1, 9, 74.

113 Comm. Ef 1, 9, 74.

114 Comm. 2 Cor 5, 20, 237; Comm. 1 Cor 15, 11, 168. 
stwa. Dwunastu miało pouczać innych o Tajemnicy Osób Bożych, a Paweł - według autora - został powołany nie tylko po to, by głosić Chrystusa poganom, ale by pouczać o Nim duchy pozostające pod władzą Szatana ${ }^{115}$.

Przepowiadanie Tajemnicy Boga miało jeszcze dalsze konsekwencje. Apostołowie — zwłaszcza Piotr i Paweł - zostali powołani również do gromadzenia na ziemi w jedną całość adoptowanych dzieci Boga, tzn. tych, którzy stanowili żywe członki Chrystusowego Ciała ${ }^{116}$. Chodzi bowiem o to, by na ziemi, która dotychczas była królestwem Szatana, wzrastało Królestwo Boże.

\section{B. Kres rozpoczętej przez Chrystusa odnowy Kościoła}

Spróbujmy w końcu ustalić, jak autor wyobraża sobie ostatnią fazę całego dzieła odbudowy i reformy Kościoła. Oczywiście nie chodzi tu o szczegółowe referowanie jego poglądów dotyczących eschatologii, to nie jest celem naszego studium, chodzi jedynie o przedstawienie zasadniczych wydarzeń, które - zdaniem Ambrozjastra - mają mieć miejsce w ostatnim etapie odbudowy Kościoła.

$\mathrm{Na}$ podstawie naszych dotychczasowych rozważań nie trudno wywnioskować, że jednym $\mathrm{z}$ najważniejszych wydarzeń będzie całkowita klęska Szatana. Jak długo bowiem on zwodzi ludzi i aniołów, tak długo nie ma mowy o pełnym dziele odbudowy Kościoła. Klęskę tę autor wiąże nierozerwalnie $z$ objawieniem majestatu Syna Bożego. Ostatnim zaś aktem będzie - według niego - objawienie zależności Syna Bożego od Ojca. Każde $z$ tych trzech wydarzeń trzeba obecnie nieco szerzej omówić.

\section{Ostateczna klęska Szatana}

Komentując listy do Tesaloniczan, Ambrozjaster wyraźnie zaznacza, że drugie przyjście Chrystusa poprzedzi wzmożona działalność Szatana. Ten bowiem do samego końca będzie uparcie obstawał przy swych pretensjach do zajęcia najwyższego stanowiska w całym świecie stworzonym. Mimo klęski w otchłani, mimo Zmartwychwstania Chrystusa, Szatan nadal nie chce w Nim uznać Syna Bożego. Ciągle dąży do tego, by jemu a nie Chrystusowi oddawano cześć Boską ${ }^{117}$.

Autor idzie w tym wypadku krok w krok za Apokalipsą Jana. Mówi więc o tym, że Szatan będzie zwodził ludzi przez fałszywego pro-

115 Comm. Ef 3, 10, 89; Comm. 1 Cor 2, 10, 27.

116 Autor nie mówi o zakładaniu na ziemi Kościoła przez Chrystusa, mówi natomiast o zakładaniu kościołów przez Apostołów (Comm. Gal 1, 17 (2), 15).

117 Comm. 2 Thes 2, 8 (2), 241. 
roka 118 i że sam wystąpi jako Antychryst ${ }^{119}$. Ten ostatni gest Szatana najpełniej i najjaśniej odkryje jego intencje. Antychryst bowiem - według Ambrozjastra - to wcielony. Szatan, który potrafi czynić cuda, tak jak czynił je Wcielony Syn Boży ${ }^{120}$. Celem zaś tych wszystkich zabiegów będzie pozyskanie wielbicieli.

Ludzie nie są w stanie definitywnie pokonać Szatana. Tego dzieła może dokonać tylko Syn Boży. On też zstąpi po raz drugi na ziemię, by walczyć z diabłem. W komentarzu do 1 Tes 4, 15 Ambrozjaster pisze: ,Sam bowiem Chrystus Pan z woli Ojca, jakby pierwszy anioł (boży) z wojskiem niebiańskim (...) zstąpi, aby w imię Boże stoczyć bitwę z Antychrystem. (...) Jest bowiem (...) wodzem i naczelnikiem wojska pańskiego, dlatego też nazywa się archaniołem ${ }^{121}$. Tekst ten zasługuje na baczniejszą uwagę. Okazuje się, że autor, nazywając Chrystusa ,archaniołem” czy ,jakby aniołem bożym” ustawia Go w jakimś stopniu na tej samej płaszczyźnie, na której stoi Szatan - upadły anioł. Kto wie, czy nie chce przez to pokazać, że diabeł nie znając prawdziwej godności Chrystusa i od samego początku traktując Go jako jednego z Archaniołów, miał jakieś podstawy do tego, by z Nim rywalizować o władzę. W ostateczności bowiem z pozycji Szatana była to rywalizacja między dwoma aniołami.

Drugie przyjście Chrystusa będzie nagłe i niespodziewane, „zjawi się jak błyskawica", mając za sobą zastępy wojska Boga Ojca i pokona Szatana i jego satelitów wtedy, gdy będą się tego najmniej spodziewali ${ }^{122}$. W momencie powtórnego przyjścia Chrystusa zaskoczeniem dla Szatana i jego zwolenników będzie jednak nie tylko nagłe zjawienie się Syna Bożego, ale również fakt powszechnego zmartwychwstania umarłych. Wtedy bowiem zostanie pokonana definitywnie, ,śmierć pierwsza" 123. Zmartwychwstanie, tak wierzących jak i niewierzących, autor łączy z sądem. Chrystus wiernych dopuści do udziału w życiu wiecznym, a niewierzących ześle na wieczną karę w otchłani ${ }^{124}$. Moment całkowitej klęski Szatana będzie więc równocześnie momentem całkowitej klęski wszystkich ludzi niewierzących.

Jeden szczegół zasługuje tu na uwagę. Pamiętamy, że Ambrozjaster jasno zaznaczał, iż Bóg w rozprawie z Szatanem nie chciał użyć siły ${ }^{125}$.

11. Comm. 1 Cor 15,52 (2), 184.

113 Comm. 2 Thes 2, 8 (1), 241.

120 Tamże.

121 Comm. 1 Thes 4, 15 (2), 227: ,ipse enim Christus dominus voluntate patris quasi primus angelus (dei) cum exercitu caelesti (...) descendet de caelo ad gerendum bellum nomine dei contra Antichristum. (...) est enim (...) dux et princeps exercitus domini, propter quod archangelus dicitur'.

12.2 Comm. 1 Thes 5, 1 (1), 228.

123 Comm. 1 Cor 15, 54, 186; Comm. 1 Tim 2, 6, 262.

124 Comm. Ef 4, 20, 104; Comm. 1 Cor 15, 22, 171.

125 Q. 2, 3, 18. 
Kiedy zaś mówi o wydarzeniach na końcu świata, nie widzi nic złego w tym, że Chrystus siłą podporządkowuje sobie opornych. Wtedy bowiem: ,wszyscy będą uznawali Chrystusa, czy to siłą czy dobrowolnie" ${ }^{126}$.

\section{Syn Boży objawia swój majestat}

Drugim, niezwykle ważnym wydarzeniem na końcu świata będzie objawienie Majestatu Syna Bożego. W jego bowiem blasku wszyscy, czy chcą czy nie chcą, poznają tajemnicę życia Bożego. Ambrozjaster w. tym wypadku stawia sprawę bardzo jasno. „Kiedy zaś wszystko wyzna Chrystusa, czy to siłą czy dobrowolnie, i zostanie poddane mocy Tego, któremu się sprzeciwiało, wszystkim zostanie objawiona tajemnica jedynego Boga, i wszelkie dziękczynienie zostanie odniesione do Ojca, od którego wszystko pochodzi, aby $\mathrm{z}$ chwilą zaprzestania przepowiadania był znany jeden Bóg $w$ tajemnicy Trójcy. (...) Tak wielka bowiem jasność i majestat objawi się w przyjściu Syna, że wszystkie moce i chóry aniołów, Jego jedynego uznają za Boga. Zbawiciel zaś wtedy oznajmi, że On nie jest tym, którego nazywają Ojcem lecz Jego Synem" 127 .

W życiu Kościoła moment objawienia Majestatu Syna Bożego będzie posiadał niezwykle doniosłe znaczenie. Dopiero wtedy całe Chrystusowe Ciało zostanie napełnione znajomością Tajemnicy Boga. Teraz Syna Bożego znają tylko wierzący, wtedy zegną przed Nim kolana również niewierzący. Kościół, czyli całe Ciało Chrystusa, każdy nawet najmniejszy jego członek w tym momencie pozna swoją Głowę. Znajomością Boga zostanie napełniony również Szatan i wszyscy niewierzący, gdyż od momentu objawienia Majestatu Syna Bożego wiara nie będzie już koniecznym warunkiem do poznania Tajemnicy ukrytej od wieków w Bogu.

Trzeba również zaznaczyć, że - według autora - dopiero w momencie objawienia Majestatu Chrystusa cały Kościól jako Chrystusowe Ciało będzie mógł w pełni poznać wielkość wyniesienia człowieka do godności dziecka, adoptowanego przez Boga ${ }^{128}$. Przybrane bowiem dzieci Boga będą uczesniczyły w tym nieskończonym Majestacie Syna Bożego ${ }^{129}$. Będzie to jeszcze jeden cios wymierzony w Szatana. Oto człowiek, najmniej doskonałe stworzenie rozumne, otrzyma godność i chwałę, o jakiej Szatanowi się nawet nie śniło, a otrzyma ją w oparciu o wiarę i pokore, których Szatanowi zabrakło.

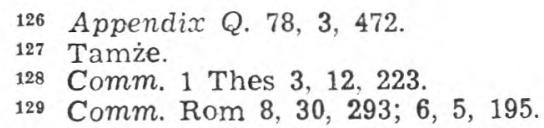




\section{Doskonała unitas professionis}

Definitywną klęskę Szatana i objawienie Majestatu Syna Bożego Ambrozjaster łączy jeszcze z jednym faktem, z objawieniem zależności Syna Bożego od Ojca. Rozważając słowa Pawła: ,na końcu Syn przekaże władzę Ojcu i sam zostanie Mu poddany" (1 Kor 15, 24), autor pisze: „Przekazanie władzy będzie polegało na tym, że kiedy, po zniszczeniu śmierci (przez powszechne zmartwychwstanie), wszystko zostanie poddane Synowi i odda Mu cześć jako Bogu, wtedy Syn okaże, że nie jest tym, z którego wszystko pochodzi, lecz przez którego wszystko istnieje. I to będzie przekazanie władzy Bogu Ojcu, czyli okazanie, że On jest Tym, od którego pochodzi wszelkie ojcostwo na niebie i na ziemi. Wtedy będzie koniec" 130 .

Nieco dalej autor podaje jeszcze dokładniejsze wyjaśnienie: ,kiedy zaś wszystko wyzna, że Chrystus jest Panem, i (wszystko) stanie się podnóżkiem nóg Jego, wtedy i sam Chrystus podda się Bogu Ojcu, aby 'Bóg był wszystkim we wszystkich'. Powiada (Paweł), że kiedy pycha wszystkich władz, mocy i księstw (upadłych aniołów) zostanie zgnieciona i uczczą Chrystusa jako Boga, wtedy i Chrystus okaże się wprawdzie Bogiem, lecz z Boga, aby pozostała najwyższa i niewysłowiona powaga jednej władzy. To właśnie znaczy, że Syn podda siebie Ojcu; to znaczy, że Bóg będzie wszystkim we wszystkich, ponieważ kiedy każde stworzenie pozna, że Chrystus jest jego Głową, głową zaś Chrystusa Bóg Ojciec, wtedy Bóg Ojciec będzie wszystkim we wszystkich. To znaczy, że każde stworzenie będzie odczuwało jedno i każdy język niebiański, ziemski i podziemny będzie wyznawał, że jeden jest Bóg, z którego jest wszystko" 131 .

Oto wspaniała wizja końca. Nadejdzie czas, gdy odnowione Ciało, w którym znajdą się wszystkie rozumne stworzenia, Syn Boży odda Ojcu. Gestem tym przekona wszystkich, że warunkiem zgody i jedności jest uznanie nad sobą głowy i że nawet On - głowa wszelkiego stworzenia - uznaje władzę Ojca, który jest Jego głową. Od tego momentu wszyscy, łącznie z Synem Bożym, nieustannie wyznawać będą swą zależność od Boga Ojca. Zapanuje idealna harmonia. Nawet duchy złe, Szatan i jego satelici, oddadzą chwałę Bogu i uznają, że Chrystus jest ich głową. Tak - zdaniem Ambrozjastra - należy rozumieć słowa św. Pawła: „na końcu Bóg będzie wszystkim we wszystkich”.

Czy mamy tu do czynienia $z$ apokatastasis panton?

Z przytoczonych fragmentów wynikałoby, że autor faktycznie jest zwolennikiem tego poglądu. Mówi bowiem o zapanowaniu pełnej jedności

130 Comm. 1 Cor 15,24 (3), 173.

131 Comm. 1 Cor 15, 28 (2), 174. 
i harmonii w całym stworzeniu. Omnis creatura, a więc wszyscy - jego zdaniem - będą odczuwali jedno i każdy język będzie wyznawał Boga. Wszyscy uznają Chrystusa za swoją głowę. To ostatnie twierdzenie najmocniej przemawia za taka koncepcją. Wiemy bowiem, że - według Ambrozjastra - nie co innego, ale właśnie uznanie Chrystusa za głowę Ciała decyduje o przynależności do tego Ciała i że nieuznawanie Go za Głowę wszelkiego stworzenia stanowi istotę grzechu aniołów!

Aby w pełni zrozumieć, do jakiego stopnia podporządkowanie wszystkiego Ojcu Niebieskiemu stanowi ukoronowanie dzieła Syna Bożego, trzeba wrócić do owej unitas professionis, jaka panowała w Kościele przed grzechem Szatana. Bowiem ta wspaniała harmonia, ta jedność, łącząca wszystkie byty rozumne, została zniszczona, a całe dzieje Kościoła - według autora - to nic innego, jak tylko zabiegi Boga, zmierzające do jej przywrócenia. I oto zaistnieje. Zaistnieje zaś w stopniu o wiele doskonalszym, niż była przed upadkiem aniołów. W momencie objawienia zależności Syna Bożego od Ojca całe Ciało Chrystusa, a więc i każdy Jego członek, zostanie wypełniony Bogiem. Odtąd On, jedyny Bóg, wyznawany i wielbiony przez wszystkich, będzie naczelną zasadą jedności.

Autor w oryginalny sposób zwraca na to uwagę. Zaznacza mianowicie, że Paweł nie ograniczył się do powiedzenia: „Bóg będzie we wszystkich", bo wtedy znaczyłoby to, że jest we wszystkich ,pprzez odczucie i powszechne uznanie, nie zaś, że wszyscy są z Niego". Powiedział natomiast, że Bóg jest ,wszystkim we wszystkich”, a więc zaznaczył, że z Niego są (wszyscy) i że On w nich jest. Z Niego, ponieważ On ich stworzył, jest zaś w nich, ponieważ w wyznawaniu wszystkich będzie jeden Bóg ${ }^{132}$. Teraz dopiero możemy zrozumieć właściwy sens tego, co autor pisze komentując Ef 4, 16: „Zabiega się o to, by stworzenie było sprowadzone do jednego przekonania (ad unum sensum) i aby było jednym ciałem, posiadając tę samą postawę wobec Pana (una professio), i aby zgadzało się w miłości Stwórcy dla swego postępu" ${ }^{133}$.

Jest zatem u Ambrozjastra mowa o powrocie wszystkiego do Boga, a mówiąc ściślej, o napełnieniu wszystkiego Bogiem. Dowodzi tego również analiza dwu podstawowych pojęć, których autor używa dla określenia procesu zachodzącego w Kościele od momentu wcielenia Syna Bożego - restaurare i reaedificare. Ujęte na tle co dopiero przytoczonych tekstów, mówiących o zakończeniu procesu odbudowy, mogą być rozumiane tylko w sensie odnowy wszystkiego, co było, a nie w sensie stwarzania czegoś nowego. Musimy pamiętać, że Ambrozjaster wciąż ma na uwadze obumarłe członki; które Chrystus powtórnie ożywia. Autor nie

132. Tamże.

133 Comm. Ef 4, 16 (3), 103. 
mówi o tym, że któryś $z$ nich należy amputować lub w ich miejsce stworzyć zupełnie nowe. Mówi tylko o odrodzeniu tego, co było jakby obumarłe. A skoro w ostatnim momencie wszelkie stworzenie uznaje Syna Bożego za swoją Głowę, wynika stąd, że wszystkie martwe członki ożyły. Czyż apokatastasis panton polega na czym innym?

Komentowane przez Ambrozjastra teksty Pisma św. mówią jednak zbyt jasno o wiecznym potępieniu, by autor tego nie dostrzegał. Stąd też wyjaśniając 15 rozdział I listu do Koryntian, napisze bez żadnych niedomówień: ,(Paweł) przyjmuje powszechne zmartwychwstanie, aby jak w Adamie wszyscy zmarli, tak sprawiedliwi jak niesprawiedliwi, tak i w Chrystusie wszyscy zmartwychwstali, tak wierzący jak niewierzący; chociaż niewierzący powstaną, by ponieść karę, zostaną jednak ożywieni; otrzymają swoje ciała już nie po to, by umrzeć, lecz cierpieć w nich bez końca, ponieważ nie chcieli uwierzyć" 134. Jak zatem Ambrozjaster godzi częste wypowiedzi o istnieniu wiecznej kary dla niewierzących z tezami o powszechnym powrocie do Boga; o przywróceniu Kościołowi pierwotnej doskonałości; o całkowitej klęsce Szatana? Bo czyż można mówić o pełnym zwycięstwie nad diabłem, skoro udało mu się część stworzeń unieszczęśliwić na całą wieczność? Albo czy można mówić o powrocie Kościoła, czyli Chrystusowego Ciała, do pierwotnej doskonałości, skoro część jego członków całą wieczność musi spędzać w otchłani?

Pytania kłopotliwe. Najłatwiej zgodzić się z autorem co do całkowitej klęski Szatana. Od momentu objawienia Majestatu Syna Bożego już nikt nie będzie uznawał go za głowę. Nawet niewierzący będą zginali kolana przed Synem Bożym, a nie przed Szatanem. A więc można powiedzieć, że - według Ambrozjastra - Szatan straci wtedy tych, których posiadał. Dużo trudniej sformułować odpowiedź na drugie pytanie. Wiele wskazuje na to, że autor zda się nie dostrzegać sprzeczności tezy o powszechnym powrocie do Boga, a więc i o przywróceniu Kościołowi pierwotnej doskonałości, z prawdą o istnieniu wiecznej kary dla niewierzących. Jego zdaniem wszyscy wrócą do Boga, bo wszyscy, tak wierzący jak i niewierzący, zostaną dopuszczeni do poznania tajemnicy Boga. Pod tym względem zapanuje jedność. Istotę bowiem przynależności do Kościoła stanowi znajomość Boga i wypływające z niej uznanie Boga.

Wynika $z$ tego, że autor całe to zagadnienie ustawia na dwu płaszczyznach. Pierwsza, to poznanie Boga. Druga, to dobra lub zła wola danego stworzenia. Według niego doskonałość Kościoła polega na doprowadzeniu wszystkich stworzeń do poznania Boga. To poznanie stanowi element istotny i decydujący o całej doskonałości Chrystusowego Ciała. Natomiast wieczna kara pewnych jego członków jest prostą kon-

134 Comm. 1 Cor 15, 22, 171. 
sekwencją ich złej woli. Sprawiedliwość domaga się, by jedni otrzymali nagrodę, a drudzy karę. Podział rodu Adama na ludzi cieszących się wiecznym zbawieniem w Niebieskim Jeruzalem i na ludzi cierpiących wieczną karę zda się - według Ambrozjastra - nie tylko nie przeszkadzać doskonałości Kościoła, ale ją uwydatnia. Ukazuje bowiem wielkość łaski Bożej, która wyniosła człowieka do udziału w życiu Syna Bożego i wielkość wiary jako gestu człowieka opowiadającego się po stronie Boga ${ }^{135}$. Niewierzący - zdaniem autora - mimo iż w przyszłości będą znali Boga w Trójcy Św., będą cierpieli wiecznie $\mathrm{z}$ tego powodu, że w okresie, w którym jedyną drogá poznania Boga w tajemnicy trzech Osób byla wiara, oni nie chcieli uwierzyć.

U Ambrozjastra mamy zatem do czynienia z możliwie do końca wykorzystaną nauką Orygenesa, określaną przez nas jako apokatastasis panton oraz z ciekawą próbą uzgodnienia jej z głoszoną przez Kościół i zawartą w Piśmie św. prawdą o wiecznej karze.

Trzeba jednak przyznać, że autor, przy swym wyraźnie gnostyckim podejściu (kładzie wielki nacisk na poznanie!) nie rozwiązał do końca tego trudnego dylematu. Wyraźnie pisze, że potępieni nie tylko nie są „dziećmi”, ale nie są nawet sługami Boga ${ }^{136}$. Nie próbuje nawet podjąć pytania, jak można mówić o owej unitas professionis, skoro pewna czẹść cierpi i cierpieć będzie zawsze. Wreszcie autor, jakby zdając sobie sprawę $\mathrm{z}$ tego, woli mówić o Kościele w odniesieniu do zbawionych, do mieszkańców Niebieskiego Jeruzalem, nie wspominając o rodzaju przynależności do Kościoła tych, którzy przebywają w otchłani. Ostatecznie Ambrozjaster jest tu w podobnej sytuacji jak Orygenes. Usiłuje za wszelką cenę zharmonizować prawdy, w które wierzy, z koncepcją teologiczną, którą tworzy. Udaje się mu to w większym stopniu niż Orygenesowi, ponieważ swoją koncepcję tworzył raczej z elementów biblijnych, a nie filozoficznych, niemniej o pełnej harmonizacji i u niego nie ma mowy.

Wypada postawić jeszcze jedno pytanie. Kiedy - zdaniem Ambrozjastra - nastąpi koniec świata? Nie wchodząc w teksty, które pozwalają zaliczyć autora do zwolenników milenaryzmu ${ }^{137}$, możemy poprzestać na stwierdzeniu, że Ambrozjaster uzależnia powtórne przyjście Chrystusa, a więc Jego ostateczne objawienie, od wypełnienia się liczby przeznaczonych do królestwa Bożego ${ }^{138}$. Wynikałoby $\mathrm{z}$ tego, że ilość adoptowanych dzieci Boga zapełniających Niebieskie Jeruzalem ${ }^{139}$ jest -

\footnotetext{
135 Comm. 1 Thes 4, 13, 226.

136 Comm. Rom 4, 23 (1), 149.

137 Comm. 1 Cor 15, 52, 183.

138 Comm. Rom 8, 19, 279.

139 Comm. Gal 4, 26, 51; tamże 4, 30, 53.
} 
zdaniem autora - ściśle przez Ojca Niebieskiego określona, a obecnie całe stworzenie oczekuje na moment, w którym ta liczba zostanie dopełniona.

\section{ZAKOŃCZENIE}

Stojąc u kresu naszych poszukiwań wypada jeszcze raz rzucić okiem na całość obrazu, wydobytego z pism Ambrozjastra. Z tej perspektywy łatwiej uchwycić zasadnicze rysy owej niewątpliwie ciekawej koncepcji eklezjologicznej, z jaką mamy do czynienia.

To, co szczególnie rzuca się w oczy, to bardzo jasne i konsekwentne ustawienie całej nauki o Kościele wokół jednej osi. Jest nią nieustanna walka, rywalizacja między Szatanem a Synem Bożym. Rywalizacja o hegemonię w Kościele. Takie ujęcie nadało eklezjologii Ambrozjastra charakter bardzo dynamiczny. W zależności od przewagi, jaką w tym zmaganiu posiada albo Szatan albo Syn Boży, autor dzieje Kościoła dżieli na dwa etapy. W pierwszym przewagę posiada Szatan. On doprowadza do rozbicia duchów niebiańskich, on również podporządkowuje sobie rodzaj ludzki. W drugim etapie przewagę posiada Syn Boży. On wyzwala ludzi z otchłani; On napełnia Kościół znajomością tajemnicy Boga w Trójcy Jedynego; On odbudowywuje i reformuje Kościół, doprowadzając go do doskonałości większej niż ta, jaką posiadał w momencie stworzeṇia.

Można zaryzykować hipotezę, że takie ustawienie zasadniczej osi eklezjologii autor znalazł w Apokalipsie. Refleksje nad tą księgą Nowego Testamentu, mówiącą o ostatnim etapie dziejów Kościoła, a zwłaszcza zestawienie Chrystusa z Antychrystem, mogły doprowadzić naszego komentora do ustawienia całych dziejów Kościoła jako nieustannego zmagania Szatana z Synem Bożym. W każdym razie wpływ Apokalipsy na interpretację nauki Pawła w ujęciu Ambrozjastra jest dość wyraźny.

Sugestia, jakoby autor odczytywał Pawła przy pomocy Jana, zwłaszcza jego Apokalipsy, jest jednak tylko hipotezą. Jej pełne uzasadnienie wymagałoby podjęcia szczegółowych badan. Faktem natomiast nie podlegającym większej dyskusji jest silne połączenie refleksji autora z teologicznymi koncepcjami apokaliptyczno-gnostyckimi pochodzenia judeochrześcijańskiego. Dowodem tego jest mocno rozbudowana angelologia, traktowanie Syna Bożego jako anioła, częste podejmowanie tematu zstąpienia do otchłani, łączenie poznania przez duchy niebiańskie tajemnicy Syna Bożego z momentem Jego wniebostąpienia ${ }^{140}$.

W samej koncepcji doskonalenia i reformowania Kościoła w podejściu Ambrozjastra na szczególną uwagę zasługują dwa tematy. Obja-

140 Tematy te szeroko omawia J. Daniélou w: Théologie du Judéo-Christianisme, Paris 1958. 
wienie Tajemnicy Trójcy Świętej oraz adopcja człowieka. Udoskonalenie Kościoła dokonuje się, według autora, przez wypełnienie wszystkich członków Chrystusowego Ciała znajomością tajemnicy Boga. Istota zaś reformy Kościoła polega na wyniesieniu człowieka, z punktu widzenia natury najmniej doskonałego członka Chrystusowego Ciała, do najwyższej godności adoptowanego dziecka Bożego. Ustawienie człowieka, adoptowanego dziecka Bożego, obok Jednorodzonego Syna Bożego jest zdaniem autora - zupełnie nową i najbardziej zaskakującą rzeczywistością W zestawieniu ze stanem Kościoła sprzed jego reformy. Oryginalna myśl Pawła o adopcji została przez Ambrozjastra w szczególny sposób wyeksponowana i bardzo umiejętnie wpleciona do całej koncepcji eklezjologicznej.

\section{LE MYSTERE DE L'EGLISE SELON AMBROSIASTER}

\section{RES U ME}

Le contenu fondamental du Mystère de l'Eglise selon Ambrosiaster est la lutte continue du Satan avec le Fils de Dieu de la priorité dans l'Eglise, à savoir qui d'entre eux doit être la tête de l'Eglise. Comme d'après l'auteur la vraie dignité du Fils de Dieu, la tête réele de l'Eglise, jusqu' à la révélation de la Sainte Trinité n'était pas connue, Satan, traitant le Fils de Dieu comme un des anges, pouvait lutter contre lui pour cette priorité.

L'auteur suppose la préexistance de l'Eglise. Au commencement l'Eglise étaił constituée par les esprits célestes, qui quoique divisés par quelques choeurs (membres) ne formaient pas qu'un seul Corps vivant dans une harmonie parfaite. Satan essayant d'atteindre la présidence dans ce Corps a detruit son unité. Dieu visant à humilier Satan a créé l'homme, et par le même, il a augmenté le Corps de l'Eglise déjà existant, d'un membre de plus. Cependant, Satan s'est assujeti aussi ce membre par son manège.

Le Fils de Dieu en entreprenant l'oeuvre d'une restauration de son Eglise est devenu l'homme et il a permis à Satan de s'entroduire dans l'enfer par porte de la morte. Là il a révélé son impeccabilité et sa divinité. Satan pour son illégale atteinte à la vie du Christ est dépourvu d'un droit de retenir les hommes dans l'enfer. Le Fils de Dieu faisant sortir les croyants de l'enfer au ciel a révélé, en même temps, aux anges sa dignité divine. A partir de ce moment toutes les créa-tures raisonnables ayant la foi jouissent de la connaissance d'une vraie dignité de la tête de l'Eglise. Satan cependant ne croyant pas en divinité du Christ persiste dans ces prétentions.

La défaite finale du Satan n'aura lieu qu' à la fin du monde où le Fils de Dieu révélera sa pleine gloire. Dès ce moment là, on n'aura plus besoin de foi pour saisir le mystère de Dieu, et Satan lui-aussi en discernant la dignité divine du Christ il lui rendra hommage comme à l'unique tête de l'Eglise. A ce moment là le Fils 
de Dieu révélera sa dépendence du Père faisant-voir par la même à Satan, qu'une réele importance ne réside pas en domination mais en subordination.

L'intervention du Christ visait à la restauration, à la perfection et à la reformation de l'Eglise. La restauration consiste à réétablir toutes les créatures raísonables dans leur unité avec Dieu; la perfection a pour sont but doter toute l'Eglise de la connaissance de Dieu; la réformation envisage l'élévation de l'homme comme le plus imparfait membre de l'Eglise, au point de vue de la nature, à la dignité la plus élévée, celle de l'enfant de Dieu. En cette élévation l'auteur discerne la plus douloureuse humiliation du Satan. Celui donc pour son orgueil de la hauteur des êtres créés a été jeté au fond dans la hiérarchie des créatures et l'homme, à son tour, de ce fond des créatures a été élévé à une telle dignité, que Satan n'a jamais supposée. L'homme, en effet est entré dans l'affinité avec Dieu, et comme l'unique des créatures il voit en Dieu non seulement son Seigneur mais aussi son Père.

Cet envisagement du Mystère de l'Eglise dans l'encadrement de la lutte du Satan contre le Fils de Dieu a apporté à l'ecclésiologie d'Ambrosiaster du charactère plus dynamique. Vue la prépondérance dans cette lutte, premièrement appartenant au Satan et ensuite au Fils de Dieu, l'auteur divise l'histoire de l'Eglise en deux étapes: celle de la victoire du Christ a été inaugurée par son incarnation, et strictement dit, par sa descente dans l'enfer.

L'angélologie largement devéloppée, le fait de compter le Fils de Dieu parmi les anges, et la mise en valeur de la descente du Christ dans l'enfer, semblent témoigner de la dépendance de l'ecclésiologie d'Ambrosiaster de la théologie judéochrétienne. 